\title{
The Financial Development of the Greek Apparel Industry during the Crisis
}

\begin{abstract}
Aristea Brazioti ${ }^{1}$
Abstract:

The difficult economic situation the country faces and the prolonged economic recession led to further contraction in consumer demand. In this economical reality the average reduction in turnover of clothing industry in many cases exceeds 30\%. The competition within the industry will intensify over the next years and as a result the market will retain either large companies with high cash ability of funds and wide sales network, or small and flexible, which target to a specific consumer's market (niche markets). Within this context, many companies of clothing industry proceeded in the closure of their stores in the last year.
\end{abstract}

\section{Key Words:}

Apparel Industry, Chain Operators, European Sector

JEL Classification: D24, L67

\footnotetext{
${ }^{1}$ School of Social Sciences, Master in Business Administration MBA Hellenic Open University, e-mail:aristea_auth@yahoo.gr
} 


\section{Introduction}

The textile and clothing industry is one of the most globalized sectors, providing employment opportunities to more than 60 million workers worldwide (Forstater, 2011), mainly women and unskilled workers. An important development in this sector, in the last decade is the consolidation of department stores in the market which intensify further competition. Thus, the examined industry, in which our business is operating, is characterized by intense competition, data arising from the numerous of clothing chains which operate in the Greek market. The big stores were developed because of the scale of the economies that they offer.

The commercial activity of the clothing industry is flourished within the seven years from 2000 to 2007. The Index of Turnover of this sector, according to sector survey of the ICAP Group (2011), has been increasing over the period 2000-2007 with an annual growth rate of $12.6 \%$. However, since 2008 the market is bearish, recording a decrease of $12.6 \%$ from 2008 to 2009 and $18.1 \%$ during the period 2009 to 2010 (Chart 1).

Chart 1: Evolution of the Turnover Index in Apparel Industry

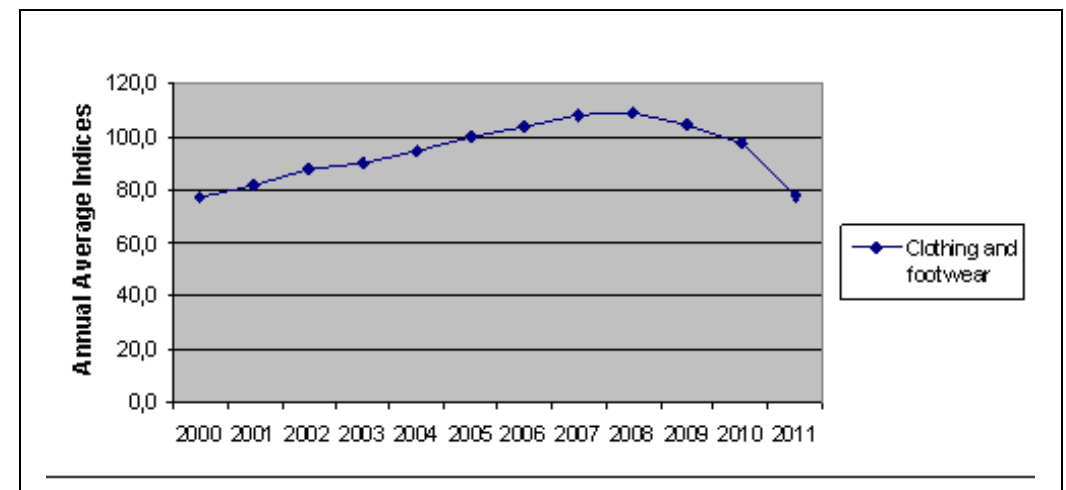

Source: ICAP 2011

As seen from the above chart, the current economic crisis has negatively affected the examined market. The retail trade in the last 4 years has shrunk considerably since it presents a relatively downward trend in total sales. According to data from the Elstat (2012), the biggest blow to the retail sector has been received by the clothing stores, dropping the index turnover surpassed $20 \%$ in 2011. Then follow the food and beverage sector with $15.6 \%$ and the fuel industry with $11.2 \%$. Specifically it is estimated at the biennium 2009 - 2011, the turnover in the clothing market decreased by $38.6 \%$. The most developed retail sector remains the supermarket industry with a share of $44.8 \%$ in total sales with a significant difference in size from the fuels and lubricants industry, which has a share of $17 \%$, and the apparel industry-footwear 
with a share of $5.6 \%$. Similarly, household equipment branches and books stores have shares of $11.5 \%$ and $7.4 \%$ respectively (Chart 2).

\section{Chart 2: Annual Change (\%) to the Volume Index in Retail Trade (2010-2011)}

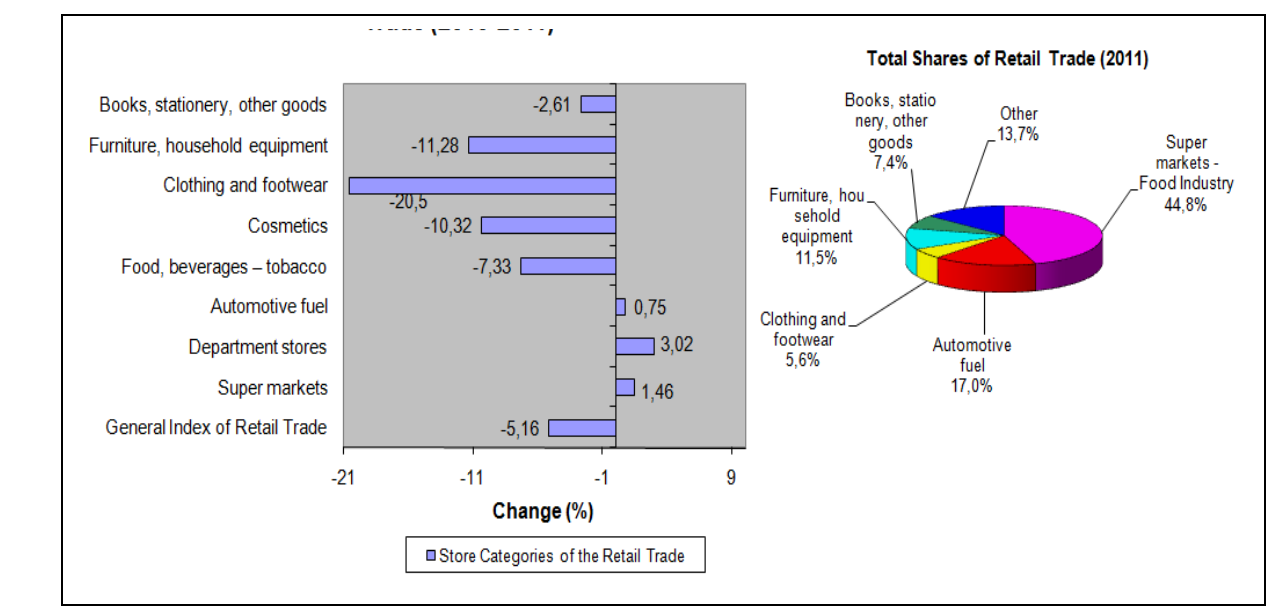

Source: ELSTAT

\section{The Profile of the Sector in Greece Today}

There can be no doubt that Greece is facing its most difficult situation in modern history. Part of the new austerity measures introduced by the government during the crisis is an additional 20\% reduction in public salaries, tax increases and layoffs in the public and private category. The current economic recession has had a direct impact on the incomes of consumers, and consequently for the business environment of the country. The vast majority of Greek consumers have reduced their spending at their discretion, both in consumer goods such as clothing, as well as for large purchases such as appliances. Moreover, prices are declined in order to attract customers in the stores. However, this strategy is proved relatively unsuccessful.

The main feature of the apparel industry the current period is the dramatic fall in turnover of enterprises engaged in it. The competition in the industry increases as the demand for products increases slowly. According to a sectoral study of ICAP, the dominant population groups regarding the expenditure of money used to buy clothes in 2011 , are women with share $53 \%$, followed by men's and children's clothing with $28 \%$ and $19 \%$ respectively (Chart 3 ). 
Chart 3: Structure of Sales of the Apparel Industry per Category (2011)

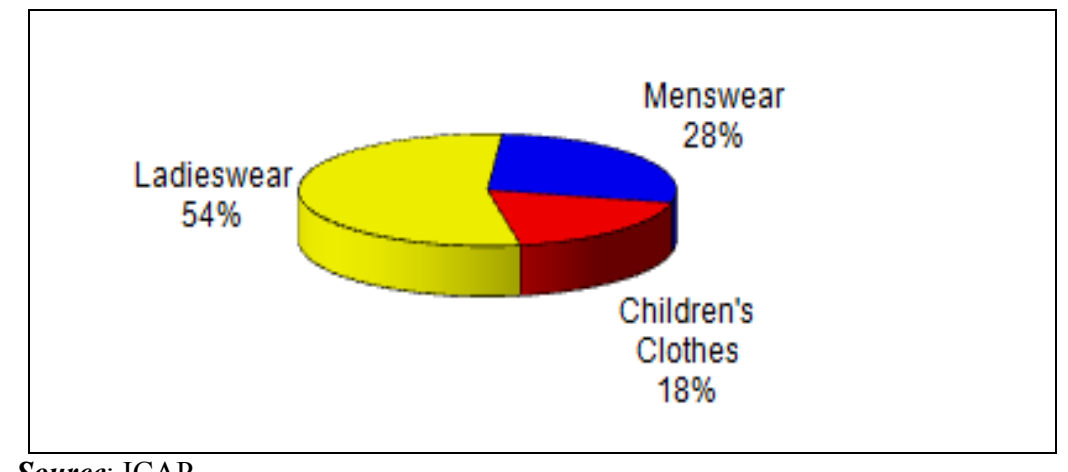

At this point it is worth mentioning that children's clothing was the least affected category of clothing in the period of crisis. Greek families tend not to cut the monthly costs of their children's clothing as in other consumer product categories, as they want their children to be dressed well. The children's clothing is a special category, as parents are quite sensitive to the examination of the costs for their children. They pay attention not only to the price but also the quality of the clothes. The poor financial condition of the country and the restrictive measures taken, seriously affected the consumption and sales. The major problem faced by companies operating in the clothing sector, as mentioned above, is the sharp drop in sales, the lack of cash and bad debts. The clothing consumption market unsurprisingly is limited by the economic crisis, which led as a domino to a decrease in orders and in sales (Greek Fashion, 2011). At the same time it led to the lengthening of the repayment obligations of customers but also to a surge of bounced checks.

On the other hand, many companies in the sector, with banking cocks closed, face, among others, the problem of poor access in lending from the banking system, which combined with the increase in borrowing costs led many companies in the industry to cash suffocation. If we add to the above the increased operating costs and the increase of the fixed overheads resulting from the constant competition with each other, it is clearly stated the modern economic reality in the industry. The reality is described by strong polarization voltages that now prevail in the clothing industry, and because of low access to bank capital and the increased lending they are based solely on cash which themselves have in order to preserve their viability.

\section{Structure and Outline of the Industry}

In recent years there have been major structural rearrangements in the clothing industry, mainly stemming from the increasing concentration of the firms which are active in this. The most substantial internationalization of the large clothing chains, 
as we will see below, contributes to the significant changes occurring in the forms of retail stores. The intense competitive pressures in the clothing market have reshaped the structure of the domestic market, leaving many small businesses and the prevalence of the major ones. According to ICAP, in 2011 served 68,000 fewer small businesses compared to 2010. Already in 2010 there were $20.1 \%$ fewer businesses than in 2009. Moreover, the path of profitability of businesses operating in the clothing industry is declining and along with the decline in domestic demand, it has made the clothing industry less efficient (Chart 4).

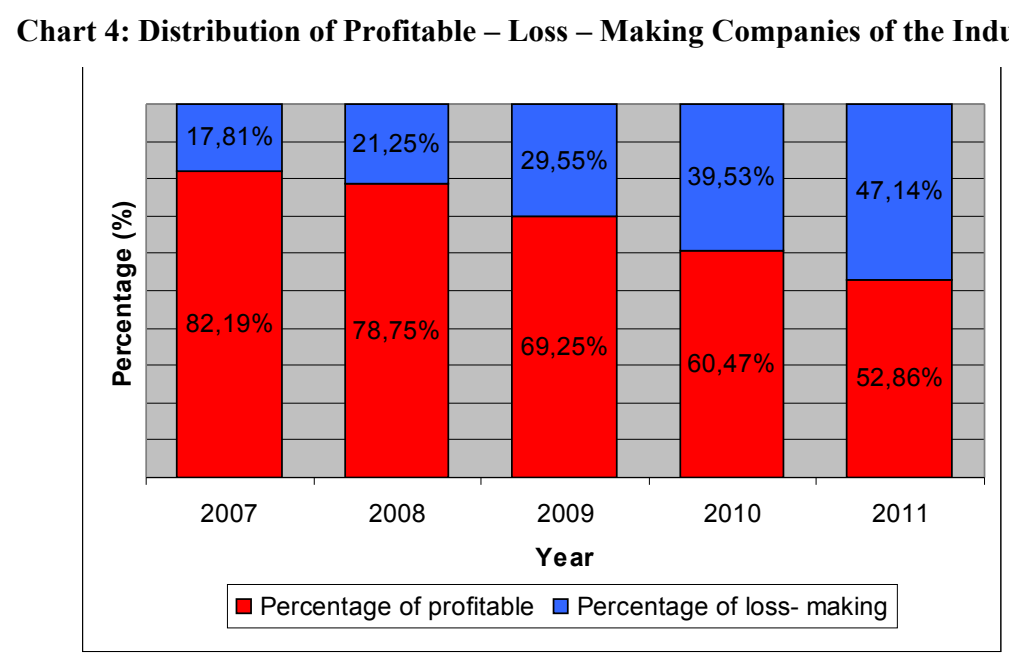

Source: ICAP 2011

According to the Esee (2011), the sales of the industry companies declined $10.9 \%$ in 2010 , while gross profit decreased by $12.1 \%$. The above, combined with the very high other operating expenses, resulted in the appearance of negative operating results in 2010. Therefore, the net result was converted to an injurious, in 2010, while EBITDA profits were decreased by $63 \%$ during the same period. The above financial data, combined with the small size of individual stores, make more difficult their economic efficiency. Small shops have difficulty in competing with large scale sales of chains composing the structure that exists in the current period in the examined industry.

The clothing sector has undergone significant changes during the past decade. The market structure changes from the entry of supermarkets which occupy a significant part of sales and launch new ways of purchasing habits. Already since the early 1990 's readymade garments chains began to grow and gradually displace the smaller shops, changing the status of the market and the competitive conditions. The strengthening of the large chains as mentioned above allows achieving economies of scale. As a result, the dynamic penetration of multinational chains (H\&M, ZARA) 
has led to the displacement of smaller retailers of the apparel market. Smaller retailers are unable to meet their current financial conditions of suffocation. The existence of a large number of chain stores and many small individual shops has resulted in fragmentation of the industry which, as seen from the chart below is characterized by a low degree of concentration (Chart 5).

Chart 5: Share of the Companies in Clothing Industry in Percentages

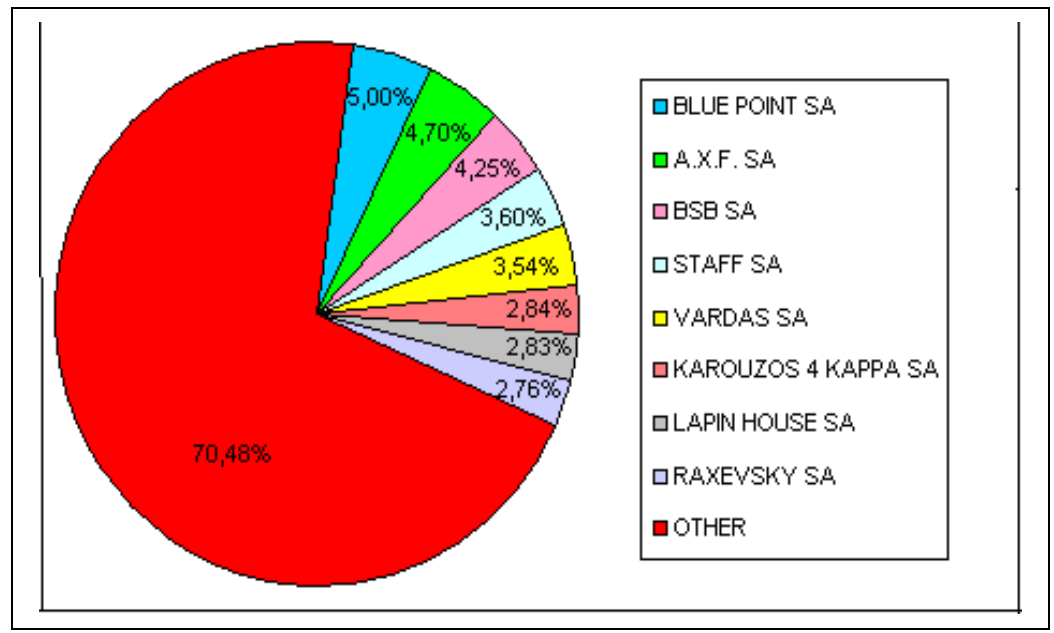

Source: ICAP Group 2011

The clothing industry is in a period of maturity, entry barriers are low and it is noticed entry of competitors. The high degree of competition prevailing in the industry is supported by numerous product offerings in all pricing and quality standards. The growth potential of the chains is up to a point due to a reduction of individual stores. The concentration of retailing from a relatively large number of chains (Fokas, Kanellopoulos, Vardas SA, Carouzos etc.) is not adversely affected and did not reduce competition. Instead as already mentioned competition in retailing is sharp and hard. Thus large part of the benefits of this competition is enjoyed by consumers in terms of better service and lower prices.

\section{Sales of Chain Operators Clothing Stores}

The clothing chain stores, which began their substantial growth in the domestic market in the early 90s, now have a strong presence and continues to expand, exerting strong pressures on individual stores. Since the company Vardas SA-which is the main subject of this work is a specialized chain, primarily engaged in marketing of branded men's and women's luxury clothes, we focus mainly on the analysis of large chains of branded clothes. The existence of extensive sales network that provides broad geographic coverage is considered an important success factor in a chain. The increase in sales and market share expansion is a primary goal of each 
chain. The cost per unit decreases as volume increases. At the same time, the chains are able to make mass orders and negotiate effectively supply conditions due to the increased volume (Siomkos, 2004).

Almost all chains are working with financial institutions, enabling consumers to purchase goods using credit cards, but with free instalments. The competition between the chains is particularly strong and in the area of credit facilities some companies have even made cards - members that offer benefits to their owners, such as reduced prices for their products throughout the year. Generally, credit facilities that are provided by the chains allow an increase of their sales, even in times of lack in cash in the market like the current one, which places them in a better position than most individual stores. The result of all these could be more competitive prices compared to most of the individual stores, taking under consideration that they trade also designer clothes.

Multinational companies hold the lion's share of the clothing market in Greece. International companies such as Zara and $\mathrm{H} \& \mathrm{M}$ are able to recapitalize their funds and to cover the loss in the Greek market through international operations. Moreover, the low platform in prices of these companies is an advantage in the current economic situation. On the other hand, clothing retailers are struggling to secure bank loans and overdrafts. Thus forced to cut their advertising budgets and in the worst case scenario to reduce the number of their employees. At this point it should be noted that expansion of Chinese stores, didn't not affect advertised and branded shops, according to market analysts. Instead, according to them, entry of Chinese shops affects individual low price stores, that aren't advertised.

\section{Determination of Apparel Industry in Europe}

With the consumption of the European households reaching nearly 500 billion $€$, the EU-27 is the largest global market for clothing (Euratex, 2010). The European retail clothing industry, like most of the sectors in retail industry has been hit by the recession and now is slowly recovering. The economic and financial crisis that hit the world in September 2008 had devastating effects on the activity of the clothing industry. In fact, the crisis which has contributed significantly to the economic slowdown is already being felt in the European clothing industry by the end of the first quarter of 2008. The consumption of clothing in the European Union has also been negatively affected by the economic crisis. Over the last five years, the major European markets, the clothing consumption has increased at a slow rate. In Germany's case, until very recently the largest European market, the consumption level in clothing even has significantly decreased. Thus, according to figures from Eurostat (2012), while 2007 was characterized mainly by an increase of $5.1 \%$ in the consumption of clothing in 2008 is recorded a drop -1\%, despite a decline in sales prices. 
However, despite the intense global competition clothing industry remains in the five largest industries in Europe. The figures for 2011 include an annual turnover of over 177 billion $€$, with 146,000 businesses employ about 1.8 million workers. It is the first time in 2008, after the 90 decade that retail sales of clothing in the European market declined. This was the result of lower sales in Europe due to the economic crisis in late 2008. During the first three quarters of 2008 it is reported an overall increase in retail sales by $1.4 \%$, but only the decrease of $-2.2 \%$ in the last quarter of the year resulted in an overall reduction in annual retail sales by $0.4 \%$. The difficult economic conditions have led to a drop in sales in the industry in 2009. However, after a bad year in 2009, when the global crisis had a negative impact on the industry, the market showed signs of recovery in 2010.

The recovery of the major euro zone economies led to increased demand for clothing products. More specifically, the improving economic data in Europe has led to an increase in consumption, which in turn led to an increase in retail sales by $3.6 \%$ in 2010. So after two years (2008-2009) of recession in retail sales in the European Union, it appears that sales gradually returned to levels before the crisis, where sales were rising at around $4 \%$ to $5 \%$ annually. The European retail clothing market, which includes women's and men's clothes and children's clothes, recorded deceleration in order to recover. In particular, retail sales, according to the Sepee (2011), registered a small increase of $1.4 \%$ in 2011 as shown in the following chart, with sales totalled 177.31 billion $€$ (Chart 6).

\section{Chart 6: Evolution of the Turnover of the European Ready-made Garments Industry}

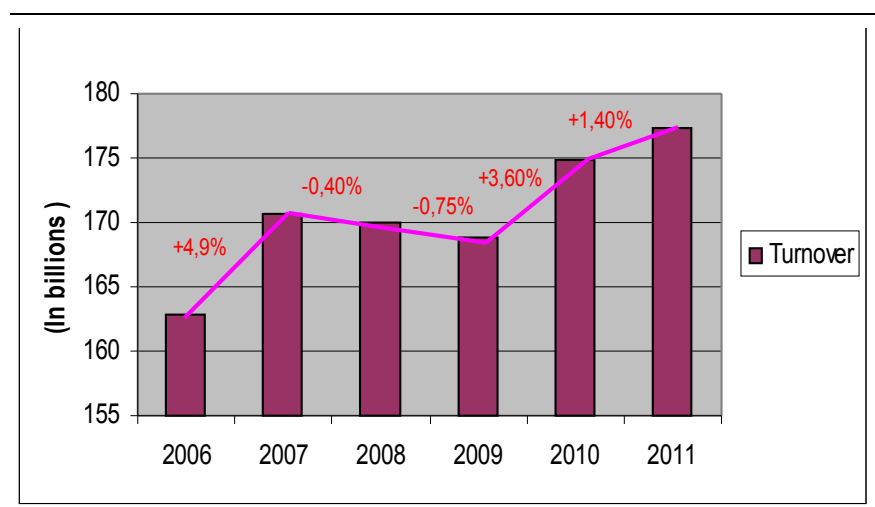

Source: Sepee

The Euro zone consists of member countries with economies which are different in size, structure, function and growth prospects. Members - countries show significant deviations $^{12}$ : apart from Germany $(+1 \%)$, France $(+0.4 \%)$ and Belgium $(+2.2 \%)$, which showed an increase in retail clothing sales, all other countries in Europe showed a decreased, the most severe decline took place in Spain (-5.7\%) in 2011. 
On the other hand, most of the newcomers showed a significant increase in retail sales in the clothing industry, such as Slovakia (99\%), Bulgaria $(+20 \%)$ and Lithuania $(+17 \%)$. In Romania, the total sales of the sector show a decrease of $-10 \%$. These differences are reflected in the GDP of each country.

The largest and most competitive economy in the Euro zone in the clothing industry is German, followed by French, Italian, and Spanish. The Greek economy is a small component of the European clothing industry with participation estimated at approximately $2.25 \%$ of the entire industry in the period $1998-2011$ according to ELSTAT. For the same period the share of the third largest economy (Italy) in the Euro zone is around $17.40 \%$, while Spain at $10.9 \%$.

Finally, shares representing Ireland and Portugal are slightly lower than the Greek and formulated to $1.89 \%$ and $1.87 \%$ respectively. Moreover, throughout Europe, clothing prices have shown a relative stability, compared with the overall increase in the price of various consumer goods. While in some countries, such as Spain or Italy, clothing prices have steadily increased, in others, such as the UK and most of Northern Europe countries prices of clothing have demonstrated significant reductions. However in early 2009 the clothing businesses experienced an even lower number of orders. Of the total sales of European industry clothing, women's clothing represent the largest share in terms of value, followed by men's and children's clothing as well as in Greek clothing industry. Regarding the structure of the European clothing industry it is noteworthy that specific chains such as Zara and $\mathrm{H} \& \mathrm{M}$, gradually replacing the small independent shops to large areas in the center of European cities. These large international players often have their own production structures, thus reducing market access for smaller clothing traditional clothing stores. As in Greek clothing industry, the bargaining power of these chains is important. Small shops have viability difficulties. In the new European economic reality these stores can't meet the intensification of cross-border competition imposed by specialized clothing chains in several European markets.

\section{Conclusion}

The apparel \& footwear industry is facing serious problems of declining demand since 2008. This is because both private consumption expenditure for the sector's products as a share of total private consumption expenditure and the real consumption decreased significantly during this period. The deep economic recession, rising unemployment and tax increases have led to a reduction in disposable income of households, which is one of the most important determinants of demand for products from the retail clothing industry. Due to the above, a dramatic drop in sales of the industry have be noted at the recent years, which in combination with the lack of bank financing aggravates the liquidity problem, threatening the viability of even large firms in the industry. The failure of debt 
collection and the reducing of the amount of sales rather exacerbated the liquidity problem.

It is obvious that in current economic context, one way out is the effective management of working capital which is crucial for the liquidity, the survival and the success of a company operating in clothing industry. According to Lazaridis and Tryfonidis (2006), managers could create profits for their companies by handling correctly the cash conversion cycle and keeping each different components (accounts receivables, accounts payables, inventory) to an optimum level. A firm could reduce its cash conversion cycle by giving award and small discounts if customers pay sooner and this could decrease Average Collection Period.

Another way to reduce companies in clothing industry their cash conversion cycle is to decrease Inventory Days on Hand without lowering their service level by implementing an S \& OP process as regard to the inventories, achieving the optimal level of stockholding and avoiding surpluses or shortages ( Oliva and Watson, 2011). These are just a few of the main actions a business can take to reduce its cash conversion cycle. It is important for a business to check first if they need extra capital before turning to loans or selling equity.

Most companies weren't prepared for such a crisis either its intensity or its duration. It seems that, in essence, the companies which will be able to come out unscathed from the crisis will be those that do not have high debt and are based on healthy own equity. Therefore, apparel companies must adopt a compression program to operating costs, thus increasing the net profit margin. The cost-cutting measures that will enhance their liquidity could relate to labor costs and the restoration of the link of payment to productivity of each employee. As outlined in the Annual report of the ESBR (2009), this relationship has been disrupted due to ripening, resulting in a company often pays twice workers with high experience, who offer exactly the same, and often less, than their much younger counterparts. Within the framework of holding their operating costs, apparel companies should move to rationalization of the network, as did on the time several clothing businesses and are in a relatively better position in terms of liquidity than the industry and their competitors. Moreover, companies in the industry should move to renegotiating and reducing their rents or to relocating.

Hereafter, the institution of outsourcing could be resulting in a substantial cost advantage. According to Sameer Kumar et al. (2008), the savings resulting at companies operating in clothing and footwear industry, because of outsourcing on various business activities, is significantly larger than firms in any other industry, primarily due to the complexity of the supply chain. This happens because the steadily increasing competition leads firms to increase their industry suppliers, their customers and products and therefore to more frequent deliveries. The outsourcing 
for example of Logistics, which is one of the major cost parameters and is the second largest cost to retail business, significantly reduces the labor costs. According to Bulut (2009), already from 1980s many branded retailers in the clothing industry have been outsourcing their business processes thereby remaining competitive in the sector.

The existing organizational structures of apparel businesses must also be replaced by new structures more efficient and more competitive in order to rethink the way they operate with a view to become more competitive in the current circumstances. The requirement for a company adapting to the new realities of the economy and the market becomes stronger during a prolonged period of low economic activity.

Companies that can't adapt to changing conditions could not long keep up with their competitors or even to survive. This adjustment can be made by coiling and development of activities of apparel business mainly in niches in which there are opportunities for Greek companies. One of these is the children's garment, that as mentioned above holds 19\% of the industry. Many apparel companies, for example, could boost the low sales, due to the economic crisis, with their entry into the market of children's clothing which have no share.

Another extremely important adaptation is the development of innovative organizational structures at the management of the company. According to Ponis et al. (2012), the branded apparel companies and not only, with a small capital investment for the construction of e shop and with minimal operating and maintenance costs, compared to a physical store, they have the ability to sell products at discounted rates mainly because of these two. Besides, as emerged from the questionnaire of this thesis, contemporary consumers have a strong preference for online stock stores.

Moreover, the domestic branded apparel business should be driven to strategic agreements and partnerships with companies abroad in the view to extroversion. In this way they will create large business units, with geographic expansion of commercial activities and a large market share to establish their brand, thus achieving scale economies (Anusua and Christoffersen, 2005 ). In this way they will survive the competition of low cost retail chains, developing alliances with suppliers in different markets, and promoted their distinctive brands (Tyler et al. 2006). Synergies between companies in clothing industry would result in an increase of profits from unique combinations of high-value research, design, sales and marketing that would allow them to act strategically by linking with overseas companies (Gereffi, 1999).

In the current period characterized by hypotonic sales and lack of bank financing, the institution of the franchise could contribute to the rapid growth of the company 
through self-financing. The company can obtain the funds required for the selffinancing for its network expansion through franchising fee that taking from businesses so as them to have a share in its final profits (www.tovima.gr, 2011). In this way it is offered to them the possibility to enter and to expand into local markets with greater speed and safety, achieving effective control to the points of sale (Lopez and Fan, 2009). Franchising proved that resistant to the crisis, since a glance to the shopping streets of the country proves that the only stores that survive are those that joined in a chain franchise. Moreover according to Franchise Success, (2011), during this crisis, 120 new stores have been launched in 2011, when the vast majority of individual shops and small retail chains simply could not manage to survive.

The clothing stores franchise, show an increase of penetration at the market by $10 \%$. According to the same source in every 160 companies putting padlock, only one franchise shop closes. As mentioned above, in 2011 closed 68,000 companies represent $25 \%$ of the market while the rate for franchise corresponds to $0,15 \%$ of the apparel market (400 stores). From the questionnaire in this master thesis showed that more than $65 \%$ of respondents, perhaps because of suspicion, trust franchise stores. These are some of the activities that need to take a business in clothing industry to ensure its survival and even its growth amidst the crisis.

Overall, most of the Greek apparel companies should undertake further restructuring of bank liabilities and freeze the growth of bank lending. From their financial analysis arises that it should limit the investment costs to the absolutely necessary by freezing the establishment of new branches so as to reduce its financial cost. Thus it will manage to avoid situations defaults as those faced some companies of the industry in recent years.

Review of surveys indicates that the strong presence of multinational low price chains poses a threat to the brand name clothing chain industry. These chains manage to reach out the medium consumer who currently has limited financial means and also gives him the ability to choose clothes that are in fashion, all the above gives them a strategic advantage. Currently, little is reported in the literature regarding the segmentation of consumers based on the acceptance of fast fashion.

Therefore, it is important to conduct research to analyse the acceptance of fast fashion across different consumer segments. Another area of research interest could be to see whether consumers perceive fast fashion brands as counterfeit due to lower price and quality offered by the retailers. Also, it will be worth examining the pricing strategy used for fast fashion apparel along with analysis of consumers' willingness to pay more for environmentally friendly and sustainable fast fashion apparel (for example, organic and green cotton apparel used by Zara and H\&M). 


\section{References}

Anusua, D. and Christoffersen, S. (2005 ), "Production Costs, Scale Economies, and Technical Change in U.S. Textile and Apparel Industries", Atlantic Economic Journal, $\mathrm{Vol} / 33$, pp. 201-213

Bulut, T. (2009), "Transnational Governance of Labour Standards: Insights from the Clothing Industry in Turkey", The Transnationalization of Economies, States, and Civil Societies, pp. 263-284.

ELSTAT (2012), Press Release, available at: www.statistics.gr/portal/page/portal/ ESYE/BUCKET/A0508/PressReleases/A0508_DKT39_DT_MM_10_2012_01_F_EN. pdf [19 February 2013].

ESBA (2011), Annual Report, available at: www.eurofound.europa.eu/publications/ htmlfiles/ef1165.htm [19 February 2013].

ESEE (2011), "The general image of Greek Trade: The economic results, the capital structure and the funding of retail stores in 2011", available at: www.esee.gr/UploadFiles/Documents/Research\%20ESEE/Etisia2012/03_Kef_2012.pdf [19 February 2013].

Euratex (2010), Annual Report, available at: www.euratex.org/content/annual-report-euratex2010 [19 February 2013].

Eurostat (2012), "Turnover and volume of sales in wholesale and retail trade - annual data, percentage change", available at: http://epp.eurostat.ec.europa.eu/portal/page/portal/ statistics/search database [19 February 2013].

Forstater, M. (2011), "Sectoral coverage of the global economic crisis - Implications of the global financial and economic crisis on the textile and clothing sector", in proceedings of ILO Sectoral Activities Programme for Sectoral assessments.

Franchise Success (2011), Stabilizing trends and Restructuring Network, Research Franchise Success: 1st Semester 2011, available at: www.franchiseblog.gr/?p=1496 [21 March 2013].

Greek Fashion (2011), Quarterly Magazine of Sepee.

Icap, (2011), Sector analysis of clothing and footwear industry

Lazaridis, I. and Tryfonidis, D. (2006), "Relationship between Working Capital Management and Profitability of Listed Companies in the Athens Stock Exchange", Journal of Financial Management and Analysis, Vol. 19, No. 1, pp. 26-35.

Lopez, C. and Fan, Y. (2009), "Internationalization of the Spanish fashion brand Zara", Journal of Fashion Marketing and Management, 13(2), pp. 279-296.

Ponis, S.E. and Masselos, V.P. (2012), "Supply chain interoperability for enhancing ebusiness adoption by SMEs: a case study from the European clothing sector", International Journal of Business Information Systems, 10(4), pp. 417-435.

Oliva, R. and Watson, N. (2011), "Cross-functional alignment in supply chain planning: A case study of sales and operations planning", Journal of Operations Management, 29(5), pp. 434-448.

Sameer, K.A. and Samad, A. (2008), "Outsourcing strategies for apparel manufacture: A case study", Journal of Manufacturing Technology Management, 19, pp. 73 - 91.

Siomkos, G. (2004), Strategic Marketing, $2^{\text {nd }}$ ed., Athens, Stamoulis Editions.

www.tovima.gr, (2011), "The franchise protects businesses from the crisis", available at: www.tovima.gr/finance/article/?aid=375630 \{21 March 2013]. 


\begin{abstract}
Abbreviations
ESBA: European Supervisory Body Restructuring

ESSE: National Confederation of Hellenic Commerce

SEPEE: Hellenic Fashion Industry Association

EURATEX: European Apparel and Textile Organization

ELSTAT: Hellenic Statistical Authority

EUROSTAT: Statistical office of the European Union

ILO: International Labour Organization

S\&OP: Sales and Operations Planning
\end{abstract}

